\title{
Study on drug use pattern in the management of the cardiovascular diseases and with comorbidities
}

\author{
Mutharasan M. ${ }^{1 *}$, Manikkannan M. ${ }^{1}$, Pachayappan K. ${ }^{1}$, Veeramani G. ${ }^{1}$, Paari ${ }^{2}{ }^{2}$
}

${ }^{1}$ Department of Pharmacy, Annamalai University, Chidambaram, Tamil Nadu, India

${ }^{2}$ Department of Medicine, RMMCH, Annamalai University, Chidambaram, Tamil Nadu, India

Received: 06 October 2021

Revised: 09 November 2021

Accepted: 10 November 2021

\section{*Correspondence:}

Dr. Mutharasan M.

Email: mutharasanpearlking@gmail.com

Copyright: (c) the author(s), publisher and licensee Medip Academy. This is an open-access article distributed under the terms of the Creative Commons Attribution Non-Commercial License, which permits unrestricted non-commercial use, distribution, and reproduction in any medium, provided the original work is properly cited.

\begin{abstract}
Background: Cardiovascular drugs are the number one cause of death globally; more people die annually from CVDs then from any other cause CVD. The purpose of this study to identify the rationality of drug prescribed for cardiovascular diseases with its comorbidities. Along with medication adherence and cost analysis. To assess the drug use pattern and to observe the drug related complications in patients with cardiovascular diseases.

Methods: A hospital based prospective observational study was conducted at department of medicine in RMMCH. A total of 79 patients were enrolled based on inclusion criteria and the data was collected using designed data collection form.

Results: Data of 79 patients were collected over 6 months mean age of patients with 19.95-60.5. Male to female ratio was 1.43:1. In cardiovascular diseases, most common disease conditions are systemic hypertension and acute coronary syndrome seen in our study population. Average drugs prescribed per patient was 4-9. Most frequently prescribed drug classes were beta blocker, antiplatelet, hypolipidemic agent. In these few minor drug interactions have been found. Study has no adverse drug reaction. The average cost of drugs was prescribed for 2500-3200 IND. Before patient counseling medication adherence and outcomes were less after counseling, medication adherence and outcomes are increased from $5 \%$ to $65 \%$.

Conclusions: The study concludes that most of the drugs were prescribed rationally according to world health organization/ESC guidelines. As behalf of this study, we could provide the information about the risk factor, leading commodities. Importance of medication adherence and cost of medications to cardiovascular drugs.
\end{abstract}

Keywords: Systemic hypertension, Acute coronary syndrome, Diabetes mellitus, Medication adherence, Drug utilization cost of medication

\section{INTRODUCTION}

Cardiovascular diseases (CVDs) are amount 1 explanation for death globally: more people die annually from CVDs then from any other course CVD. People with CVD/ who are high cardiovascular risk (due to presence of $1 /$ more risk factor like hypertension, diabetes, hyperlipidemia/ already established disease) need early detection and management using counseling and drugs as appropriate. ${ }^{1}$
CVDs were included coronary cardiopathy, cerebrovascular disease, peripheral arterial disease, rheumatic cardiovascular disease, congenital heart condition, deep vein thrombosis and embolism. The foremost important behavioral risk factors of heart condition and stroke are unhealthy diet, physical inactivity, tobacco use and harmful use of alcohol. Cessation of tobacco use, reduction of salt within the diet, 
consuming fruits and vegetables, regular physical activity and avoiding harmful use of alcohol have been shown to scale back the danger of upset. ${ }^{2}$

The most common symptoms of stroke sudden weakness of the face, arm, or leg, most frequently on one side of the body. Rheumatic heart condition is caused by damage to the gut valves and muscular tissue from the inflammation and scarring caused by infectious disease. Symptoms of infectious diseases include: fever, pain and swelling of the joints, nausea, stomach cramps and vomiting.

At least three quarters of the world's deaths from CVDs occur in low-and middle- income countries. At macroeconomic level, CVDs place an important burden on the economies of low- and middle-income counters.

Examples of population-wide primary interventions are comprehensive tobacco control polices, taxation to cut back the intake of foods that are high in fat, sugar and salt, building walking and cycle paths to extent physical activity. $^{3}$

For secondary prevention of CVDs is treatment with medications like aspirin, beta-blockers, angiotensinconverting enzyme inhibitors, statins.

In addition, costly surgical operations are arteria bypass, balloon angioplasty, valve repair and replacement, heart transplantation, implant operations are sometimes required to treat CVDSs. ${ }^{4}$

Cardiac medications won to treat arteria disease (CAD) such as anticoagulants, antiplatelet agents and dual antiplatelet therapy, ACE inhibitors, angiotensin II receptor blockers, angiotensin receptor-Neprilysin inhibitors, beta blockers, calcium channel blockers, cholesterol-lowering medications, digitalis preparations, diuretics, vasodilators.

Some patients who have heart attacks, that have stents placed in their coronary arteries, or undergo arteria bypass graft surgery (CABG) are treated with two types of antiplatelet agents at the identical time to stop bleeding. This is often called dual antiplatelet therapy (DAPT). ${ }^{5}$

Based on the above content, a pursuit on study on drug use pattern in management of CVDs with comorbidities was conducted. Patients with arteria disease, cerebrovascular diseases, systemic hypertension, infarction and stroke both out and in patient who visited the department of medicine at Rajah Muthiah medical college and hospital monthly and who met inclusion criteria was included within the study. ${ }^{6}$

\section{METHODS}

A prospective observational study was conducted in the department of medicine at Rajah Muthiah medical college and hospital, Annamalai university, Annamalai Nagar,
Chidambaram-608002 during the period of six months from November 2019 to April 2020. Patients who attended medicine outpatient and inpatient department with the complaints of coronary artery disease, cerebrovascular diseases, systemic hypertension, myocardial infarction and Stroke between the age group of 20-60 and above years were included in the study after obtaining their signed consent form. The patients were given an explanation on the procedure, objective, and benefits of the research before filling up the informed consent.

The data was collected using designed data collection form. Patients with other co-morbidities conditions like diabetes mellitus, depression and anxiety, chronic obstructive pulmonary disease and anaemia ill patients were not included in the study. Patients who are not willing to participate in this study are under the age group of 20 and above 40 years was excluded.

Recording of complete identity of the patients in the data collection sheet. The information regarding patient's demographic details, medication history, laboratory data and therapeutic management were collected from patient's case sheets only. The following parameters were analysed; biochemical profile such as haemoglobin level, systemic blood pressure, serum cholesterol level, LFT, RFT and all data around the culture was collected from lab report.

\section{Statistical analysis}

The data was collected and entered in Microsoft excel software 2007 and interpreted by descriptive statistics that was presented to analyse and express the report as counts and percentages in the form of the tables, charts and graphs.

\section{RESULTS}

Sample for research included 79 patients who visited both outpatient and inpatient service with CVDs and with comorbidities in department of medicine at RMMCH. The research was conducted over a period of 6 months from November 2019 to April 2020.

Totally 79 patients of both the gender with CVDs and with comorbidities were recruited for the present study. Among them 47 patients were male and 32 patients were female. CVDs are more common in people between $61-70$ years of age (Table 1).

Table 1: Age wise distribution.

\begin{tabular}{|llll|}
\hline $\begin{array}{l}\text { Age division } \\
\text { (Years) }\end{array}$ & Male & Female & Total (\%) \\
\hline Below 40 & 2 & - & $2(2)$ \\
\hline $\mathbf{4 1 - 5 0}$ & 11 & 3 & $14(17.7)$ \\
\hline $\mathbf{5 1 - 6 0}$ & 14 & 6 & $20(25)$ \\
\hline $\mathbf{6 1 - 7 0}$ & 12 & 15 & $27(34)$ \\
\hline $\mathbf{7 1 - 8 0}$ & 8 & 6 & $14(17.7)$ \\
\hline $\mathbf{8 1}$ above & & 2 & $2(2)$ \\
\hline
\end{tabular}


In total 79 patient's majority of patients (36) were diseased with acute coronary syndrome nearly $46 \%$ as shown in the Table 2.

Table 2: Disease wise distribution.

\begin{tabular}{|l|l|l|}
\hline Disease type & $\begin{array}{l}\text { No. of } \\
\text { patients }\end{array}$ & $\begin{array}{l}\text { Percentage } \\
(\%)\end{array}$ \\
\hline $\begin{array}{l}\text { Systemic } \\
\text { hypertension }\end{array}$ & 30 & 38 \\
\hline $\begin{array}{l}\text { Acute coronary } \\
\text { syndrome }\end{array}$ & 36 & 46 \\
\hline $\begin{array}{l}\text { Atrial fibrillation } \\
\text { Ischemic heart } \\
\text { disease }\end{array}$ & 6 & 7.5 \\
\hline
\end{tabular}

Among cardiovascular drugs metoprolol (34\%) were prescribed more in antihypertensive drugs as shown in the Table 3.

Table 3: Antihypertensive drugs.

\begin{tabular}{|lll|}
$\begin{array}{l}\text { Antihypertensive } \\
\text { drugs }\end{array}$ & $\begin{array}{l}\text { No. of } \\
\text { prescription }\end{array}$ & $\begin{array}{l}\text { Prescription } \\
\text { rate (\%) }\end{array}$ \\
\hline Metoprolol & 27 & 34 \\
\hline Atenolol & 7 & 8 \\
\hline Amlodipine & 19 & 24 \\
\hline Nifedipine & 2 & 2 \\
\hline Enalapril & 18 & 22 \\
\hline Telmisartan & 3 & 3 \\
\hline Propranolol & 1 & 2 \\
\hline
\end{tabular}

Isosorbide dinitrate (17\%) were prescribed more in antianginal drugs, atorvastatin $(75 \%)$ was prescribed more in hypolipidemic agents, clopidogrel (53\%) were prescribed in the antiplatelet drugs as shown in the Table 4.

Table 4: Anginal, hypolipidemic, antiplatelet drugs.

\begin{tabular}{|l|l|l|}
\hline Variables & $\begin{array}{l}\text { No. of } \\
\text { prescription }\end{array}$ & $\begin{array}{l}\text { Prescription } \\
\text { rate }(\%)\end{array}$ \\
\hline $\begin{array}{lll}\text { Antianginal drugs } \\
\text { Nitroglycerin }\end{array}$ & 3 & 3 \\
\hline $\begin{array}{l}\text { Isosorbide } \\
\text { dinitrate }\end{array}$ & 14 & 17 \\
\hline Hypolipidemic agent & & \\
\hline Atorvastatin & 60 & 75 \\
\hline Antiplatelet drugs & 20 & 25 \\
\hline Aspirin & 42 & 53 \\
\hline $\begin{array}{l}\text { Clopidogrel } \\
\text { Aspirin }+ \\
\text { clopidogrel }\end{array}$ & 7 & 8 \\
\hline
\end{tabular}

Digoxin $(45 \%)$ were prescribed more in ionotropic drugs, heparin $(8 \%)$ was prescribed more in anticoagulant drugs, furosemide $(30 \%)$ was prescribed more in diuretics drugs (Table 5).
Table 5: Inotropic, anticoagulant, diuretic drugs.

\begin{tabular}{|lll|}
\hline Variables & $\begin{array}{l}\text { No. of } \\
\text { prescription }\end{array}$ & $\begin{array}{l}\text { Prescription } \\
\text { rate }(\%)\end{array}$ \\
\hline Inotropic drugs & & \\
\hline Digoxin & 34 & 45 \\
\hline Anticoagulant drugs & \\
\hline Heparin & 7 & 8 \\
\hline Enoxaparin & 3 & 3 \\
\hline Diuretic drugs & & \\
\hline Furosemide & 24 & 30 \\
\hline $\begin{array}{l}\text { Furosemide }+ \\
\text { spironolactone }\end{array}$ & 9 & 11 \\
\hline
\end{tabular}

In co-morbidities patients' metformin (25\%) were prescribed more in diabetic drugs.

Table 6: Co-morbidities drugs.

\begin{tabular}{|lll|}
\hline Diabetic drugs & $\begin{array}{l}\text { No. of } \\
\text { prescription }\end{array}$ & $\begin{array}{l}\text { Prescription } \\
\text { rate }(\%)\end{array}$ \\
\hline Metformin & 20 & 25 \\
\hline Glimepiride & 13 & 16 \\
\hline Human insulin & 9 & 11 \\
\hline
\end{tabular}

By cost analysis of cardiovascular drugs, best price for metoprolol (2.4 IND) in Cipla brand, for isosorbide dinitrate (0.82 IND) in Mankind brand, for atorvastatin (1.9 IND) in Mankind brand, for clopidogrel (2.9 IND) in Mankind brand, for digoxin (1.3 IND) in Cipla brand (Table 7).

Table 7: Cardiovascular drugs cost analysis.

\begin{tabular}{|llll|}
\hline $\begin{array}{l}\text { Anti- } \\
\text { hypertensive } \\
\text { drugs }\end{array}$ & $\begin{array}{l}\text { Sun } \\
\text { pharma } \\
\text { (tab) }(\mathrm{Rs})\end{array}$ & $\begin{array}{l}\text { Cipla } \\
(\text { tab) } \\
(\mathrm{Rs})\end{array}$ & $\begin{array}{l}\text { Mankind } \\
\text { (tab) } \\
(\mathrm{Rs})\end{array}$ \\
\hline $\begin{array}{l}\text { Metoprolol } \\
\text { Isosorbide } \\
\text { dinitrate }\end{array}$ & 4.5 & 2.4 & 3.8 \\
\hline Atorvastatin & 0.84 & 0.87 & 0.82 \\
\hline Digoxin & 0.77 & 6.12 & 1.9 \\
\hline Clopidogrel & 7.6 & 1.3 & - \\
\hline Heparin & - & 5.36 & 2.9 \\
\hline
\end{tabular}

In total 79 patients, on pre-patient counselling medically adhered patients were $50(64 \%)$ and non-adhered patients were $4(5 \%)$. On post-patient counseling non-adhered patients were 0 and medically adhered patients were 69 (88\%) (Table 8).

Table 8: Adherence rate.

\begin{tabular}{|lll|}
\hline Adherence & $\begin{array}{l}\text { Pre-patient } \\
\text { counselling, }(\%)\end{array}$ & $\begin{array}{l}\text { Post-patient } \\
\text { counselling, }(\%)\end{array}$ \\
\hline $\begin{array}{l}\text { Non- } \\
\text { adherence }\end{array}$ & $4(5)$ & $0(0)$ \\
\hline $\begin{array}{l}\text { Partial } \\
\text { adherence }\end{array}$ & $25(31)$ & $10(12)$ \\
\hline Adherence & $50(64)$ & $69(88)$ \\
\hline
\end{tabular}




\section{DISCUSSION}

The knowledge we acquired from the study to discuss briefly about rational drug usage of CVDs and its comorbidities. Therefore, drugs causing ADR and drug interactions were found in over study and also to improve the patient quality of life, treatment cost by patient counseling, cost analysis.

In our study 79 participants were observed for the important findings to provide quality care for the cardiovascular patients and to provide information for cost of the health care professionals. In our study population consisting of $47(59 \%)$ of male and $32(41 \%)$ of female patients. Male patient has more risk of developing cardiovascular disease than female due to cigarette smoking and alcohol consumption, majority patient was in the age of 61 to 70 . Because they have lack of exercise, some have poor socio-economic status. It similar to the results of a study done by Shah et al. The majority of the patients $(72 \%)$ were in age group of $65-74$ years. There was a male preponderance $(60.03 \%)$. Of the total 1026 disease conditions, CVDs were the most common $(86.75 \%){ }^{6}$

After the age of 40 itself most of the people get affecting with cardiovascular disease in most developing countries. Majority of people has ACS and SHTN in the obtained data containing average number of drugs is 10 with its comorbidities. The drugs are prescribed with accordance to the standard WHO guidelines. It similar to the results of a study done by Shenoy et al. ${ }^{10}$

There is no adverse drug reaction seen in any cases, but some minor drug interactions are seen only in few cases. Our study is compared with the previous studies, it has little changes gives in treatment.

Patient counselling have some influence towards medication adherence.

We justify that our studies give good knowledge about the drugs used in CVDs and its co-morbidities, medication adherence, cost effectiveness of the low-income people, why we say this CVDs are the dangerous illness cause death throughout the world. It should be helpful for further studies carried out for the quality of the treatment. It was compared with the result of study done by Revikumar. ${ }^{20}$

Limitations of the study was that mentally ill and unconscious patients and patients treated at ICU was excluded. patients who are not willing to participate in the study and Patients under the age group of 54 were not included.

\section{CONCLUSION}

The present study concluded that most of the drugs were prescribed rationally according to current guidelines. In addition to prescribing drugs, patients should be educated about the risk factors of CVD and how they can be prevented. For prescribing the CVD drugs, the cost comparison analysis study talked about less expensive and equal efficacy of drugs in each category of cardiovascular drugs. This might be helpful to drug use pattern for physicians for economically bothered patients. Hence the prescribing pattern of the CVD drugs depends upon the comparison of economical and effective status of the drug from each category of CVD drugs to reducing the symptoms and risk factors of co-morbidities. Among prescribing pattern observation in CVD patients, mainly antihypertensive drugs such as beta-adrenergic blockers, calcium channel blockers, diuretics, angiotensin converting enzyme inhibitors, vasodilator used for the management. In final analysis, we found that regular monitoring must be implemented to improve the patient compliance and achieve a better outcome. The medication adherence was greatly increased by patient counselling given by the clinical pharmacist.

\section{ACKNOWLEDGEMENTS}

Author would like to thanks to department of medicine, RMMCH, Annamalai university and all the post graduate students, department of medicine, RMMCH, Annamalai university, Annamalai nagar for their valuable cooperation and suggestions for carryout our work in successful manner.

\section{Funding: No funding sources}

Conflict of interest: None declared

Ethical approval: The study was approved by the Institutional Ethics Committee

\section{REFERENCES}

1. WHO Collaborating Centre for Drug Statistics Methodology. Guidelines for ATC classification and DDD assignment 2018. Oslo, Norway. 2017. Available

at: https://www.whocc.no/atc_ddd_index_and_guideline s/guidelines.

2. WHO policy perspectives in medicines. Promoting rational use of medicines: World Health Organization. 2002. Available at: https://www.who.int/activities/promoting-rationaluse-of-medicines.

3. WHO. Essential Medicines and Health Products Information. 2014. Available at: https://www.who.int/southeastasia/healthtopics/essential-medicines.

4. Meena DK, Jayanthi M. Drug utilization research: a review. Int J Basic Clin Pharmacol. 2019; 8(2):354

5. Gupta AK, Mishra S. Prescription audit study in a tertiary care hospital using the anatomical Therapeutic chemical and defined daily dose classification concept. Int J Basic Clin Pharmacol. 2014;3:889-901.

6. Shah RB, Gajjar BM, Desai SV. Drug utilization pattern among geriatric patients assessed with the anatomical therapeutic chemical classification / defined daily dose system in a rural tertiary care 
teaching hospital. Int J Nutr Pharmacol Neurol Dis. 2012;2:258-65.

7. Prakash RS, Anuradha MG, Prakruti PA. Study of Drug Utilization Pattern According to Daily Define Dose in Intensive Care Unit (ICU) at Tertiary Care Teaching Hospital. Indiayp. 2015.4.9

8. Truter I. A review of drug utilization studies and methodologies. Jordan J Pharmaceut Sci. 2008;1(2):91-103.

9. Shewade DG, Pradhan SC. Auditing of prescriptions in Government teaching hospital and four retail medical stores in Pondicherry. Ind $\mathrm{J}$ Pharmacol. 1998;30:408-10.

10. Shenoy S, Rao J, Sen A, Kumar V. Evaluation of the drug-prescribing pattern in elderly patients in tertiary care hospital. Ind J Pharmacol. 2006;38(1):90.

11. Uppal R. Utilization of antimicrobials for caesarean section in a district hospital in India. Apua Newsl. 1990;8:2.

12. Uppal R. Antimicrobial drug usage in urology. Int $\mathbf{J}$ Clin Pharmacol Ther Toxiocol. 1991;29(a):336-8.

13. Duke MNG. Drug Utilization Studies-Method and Uses. European Series No. 45. Copenhagen, Denmark: WHO Regional Publications. 1993;1-4.

14. Ramsay LE. Bridging the gap between clinical pharmacology and rational drug prescribing. Br J Clin Pharmacol. 1993;35(6):575-6.

15. Gupta N, Sharma D, Garg SK, Bhargava VK. Auditing of prescriptions to study utilization of antimicrobials in a tertiary hospital. Indian $\mathbf{J}$ Pharmacol. 1997;29(6):411-15
16. Benet LZ. Principles of prescription order writing and patients compliance instructions. In: Goodman AG, Rail TW, Nies AS, Taylor P, editors. Goodman and Gilman's The Pharmacological Basis of Therapeutics. 8th edition. New York: Pegamon Press Inc. 1991;1640.

17. Shrishlya MV, Mahesh K, Nagarani MA, Sr Mary C, Andrade C, Venkataraman BV. Prescription audit study in an Indian hospital setting using the DDD (defined daily dose). Concept. Indian J Pharmacol. 1994;26(1):23-8.

18. Wettermark B, Almarsdóttir AB, Andersen M, Benko $\mathrm{R}$, Bennie $\mathrm{M}$ et al. Drug Utilization Research: Methods and Applications, First Edition. Elsevier's M, eds. John Wiley and Sons Ltd; 2016.

19. WHO Collaborating Centre for Drug Statistics Methodology. Available https://www.whocc.no/atc_ddd_index.

20. Revikumar KG. Pharmacoepidemiology and Pharmacoeconomics Concepts and Practice. PharmaMed Press/BSP Books. 2016.

Cite this article as: Mutharasan M, Manikkannan M, Pachayappan K, Veeramani G, Paari N. Study on drug use pattern in the management of the cardiovascular diseases and with comorbidities. Int $\mathbf{J}$ Basic Clin Pharmacol 2021;10:1380-4. 